\title{
杭体とジオグリッドの併用における 荷重分担効果
}

\author{
弘中淳市 $1 \cdot$ 渡邊陽一 $2 \cdot$ 大谷順 $3 \cdot$ 平井貴雄 4
}

\begin{abstract}
軟弱地盤上に道路盛土などを造成する際に, 不同沈下を抑制することを目的として深層混合処理工法に代表 される改良柱体とジオグリッドを併用する工法が採用されている，本工法の特長は，改良柱体上にジオグリッ ドを敷設することにより，改良柱体間の未改良地盤に盛土荷重を直接作用させることなく改良柱体に伝達させ る荷重分担効果が発揮されるため, 低改良率施工を可能とするものである. そこで, この荷重分担効果をより 効率的に発揮させるためには，ジオグリッドを敷設した際の地盤内挙動を非破壊かつ3次元的に把握すること が重要であると考える，本報では，模型地盤の沈下実験を実施し，杭頭地盤の挙動をX線CTスキャナにて非破 壊検査することにより，ジオグリッドによる荷重分担効果について報告する.
\end{abstract}

キーワード : X線CT法, 杭体, ジオグリッド, 荷重分担効果

\section{1.はじめに}

軟弱地盤上に道路盛土などを造成する際に，不同沈下 を抑制することを目的として深層混合処理工法に代表さ れる改良柱体とジオテキスタイルを併用する工法が採用 されている ${ }^{1)}$. 本工法の特徵は, 沈下に伴う杭間地盤の アーチ作用とジオテキスタイルの引張力による荷重分担 効果 ${ }^{2)}$ が発揮されるため, 低改良率施工を可能とするも のである. しかし，この荷重分担効果に与える要因とし ては, 敷設するジオテキスタイルの材料特性や敷設条件, 改良柱体の改良率, 基礎地盤および杭頭地盤の土質特性 など様々なものが考えられる. そこで本研究では, 近年 地盤工学分野においても適用されつつ X線 CT スキャナ 3) を用いることより, 沈下に伴う杭間地盤のア一チ作用 とジオテキスタイルの併用による荷重分担現象を解明し, 最も効率的な改良率とジオテキスタイルの敷設条件につ いて検討している ${ }^{4)}$. 本報では, 模型実験および FEM 解析によって杭頭地盤のアーチ作用について把握し, ジ オテキスタイルを併用することによる効果について考察 するものである.

\section{2. 実験概要}

本実験では, 沈下に伴う杭間地盤のア一チ作用とジオ テキスタイル併用時における地盤内挙動を非破壊で把握
することを目的に, X 線 CT スキャナにて非破壊検査可 能な実験条件で比較した. 図-1 に模型地盤の概要を示 す. 内径 $126 \mathrm{~mm}$, 高さ $200 \mathrm{~mm}$ のアクリルモールド内に, 着底杭を想定して杭径 $D=15 \mathrm{~mm}$ の杭を杭間 $45 \mathrm{~mm}$ (3D) で 4 本固定し, 杭が貫通できるような穴をあけた底板を 一定速度で沈下させる沈下板装置を取り付けた. この底 板を一定速度で沈下させることにより，盛土基礎地盤の 沈下を想定している. また, 杭頭の盛土地盤を想定して 底板上部に地盤材料を高さ $100 \mathrm{~mm}$ まで相対密度 $80 \%$ に 締固め, $32 \mathrm{kPa}$ の上載荷重を作用させた. 表-1 に実験ケ 一スを示す．実験は，CASE1 の条件を基本とし，地盤 材料および敷設する補強材による影響をそれぞれ検討し た．実験に用いた地盤材料は，表-2 に示すような特性 を有し，それぞれ絶乾状態で比較した. 実験に用いたジ オテキスタイルは, モールド形状にカットしたポリエチ
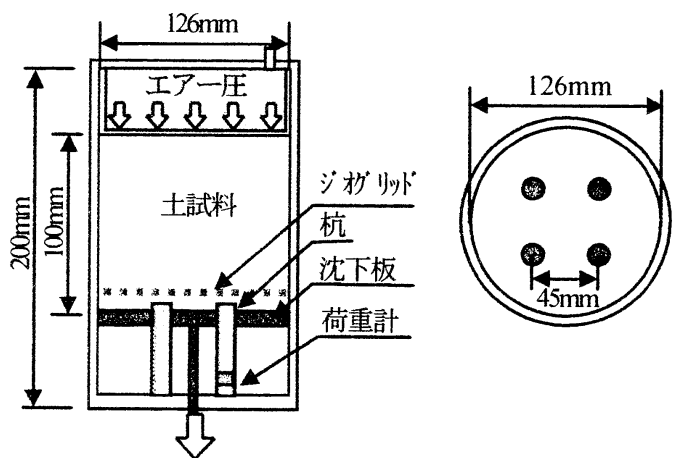

図-1 模型地盤の概要

1正会員，三井化学産資株式会社，技術開発部 （广346-0028埼玉県久喜市河原井町9番地）

2 学生会員, 熊本大学大学院自然科学研究科 (T860-8555 熊本県熊本市黒髮 2 丁目 $39-1$ )

3正会員, 熊本大学工学部環境システム工学科 教授（テ860-8555 熊本県熊本市黒髪2丁目39-1）

${ }^{4}$ 正会員, 三井化学産資株式会社，事業本部（广113-0034 東京都文京区湯島3丁目39-10） 
表-1 実験ケース

\begin{tabular}{c|c|c}
\hline & 地盤材料 & 補強材 \\
\hline CASE1 & 豊浦砂 & なし \\
\hline CASE2 & 硅砂7号 & なし \\
\hline CASE3 & 硅砂 8号 & なし \\
\hline CASE4 & 粉体粘土 & なし \\
\hline CASE5 & 豊浦砂 & Grid-A \\
\hline CASE6 & 豊浦砂 & Grid-B \\
\hline CASE7 & 硅砂 7号 & Grid-B \\
\hline CASE8 & 硅砂 8 号 & Grid-B \\
\hline CASE9 & 粉体粘土 & Grid-B \\
\hline
\end{tabular}

表-2 試料の土質特性

\begin{tabular}{c|c|c|c}
\hline & $\begin{array}{c}\text { 有效粒径 } \\
D_{50}(\mathrm{~mm})\end{array}$ & $\begin{array}{c}\text { 均等係数 } \\
\mathrm{U}_{\mathrm{C}}\end{array}$ & $\begin{array}{c}\text { 内部摩擦角 } \\
\phi(\mathrm{deg})\end{array}$ \\
\hline 豊浦砂 & 0.19 & 1.56 & 39.4 \\
\hline 硅砂 7 号 & 0.15 & 1.63 & 36.0 \\
\hline 硅砂 8 号 & 0.12 & 1.86 & 33.9 \\
\hline 粉体粘士 & 0.0026 & 10 & 25.9 \\
\hline
\end{tabular}

表-3 ジオグリッドの特性値

\begin{tabular}{c|c|c|c|c}
\hline & $\begin{array}{c}\text { 目合い } \\
(\mathrm{mm})\end{array}$ & $\begin{array}{c}T_{\max } \\
(\mathrm{kNm})\end{array}$ & $\begin{array}{c}E A \\
(\mathrm{kN})\end{array}$ & $\begin{array}{c}E I \\
\left(\mathrm{kNm}^{2}\right)\end{array}$ \\
\hline Grid-A & $2 \times 2$ & 0.6 & 15 & $1.7 \times 10^{8}$ \\
\hline Grid-B & $9 \times 9$ & 3.0 & 67 & $1.3 \times 10^{6}$ \\
\hline
\end{tabular}

レン製ジオグリッドで，表-3 に示すような目合いおよ び風性の異なる 2 種類をそれぞれ杭頭に敷設して比較し た. 実験方法は, $1 \mathrm{~mm} / \mathrm{min}$ の一定速度で底板を $5 \mathrm{~mm}$ 沈 下させ，実験前後の地盤内状況を X 線 CT 撮影した. な お, X線 CT スキャナに関する詳細は参考文献 ${ }^{5)}$ を参照さ れたい.

\section{3. 実験結果および考察}

\section{（1）杭頭地盤のア一千作用}

本節では, 荷重分担効果における杭間地盤のア一チ作 用について把握するため, 4 種類の地盤材料を用いて比 較した. 図-2 に, 沈下板 $5 \mathrm{~mm}$ 沈下後における CASEI〜 4 の X 線 CT 画像を示す.ここでは X 線 CT 撮影によつ て得られた断面画像を重ね合わせ, 非破壊状態にて杭頭 地盤の状態を鈶直方向に 2 分割した縦断面画像を, 密度 変化領域をより可視化しやすくするために密度と正の相 関関係にある CT 值 ${ }^{5)}$ によって色分けしている. CASE1 は, 沈下に伴い杭頭地盤にて密度変化が局所的に卓越す る傾向にあり, 杭頭部にコーン状の高密度領域が形成さ れる. その周辺を低密度領域が包み込むように形成され， それぞれの杭から形成された密度変化領域はある高さか ら一体化し， 2 本の杭間地盤における密度変化角度: $\theta$ は 約 38 度である. CASE2, 3 の密度変化はそれぞれ CASE1 と類似しているが, 2 本の杭間地盤における密度変化角 度: $\theta$ は若干異なり, CASE2 が約 48 度, CASE3 が約 55 度である. 一方, CASE4は CASE1〜3の挙動とは明らか

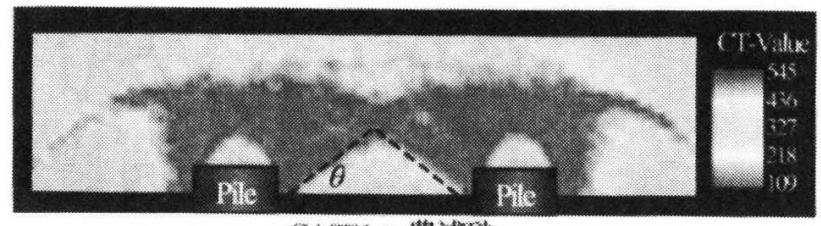

CASE1 : 曹浦砂

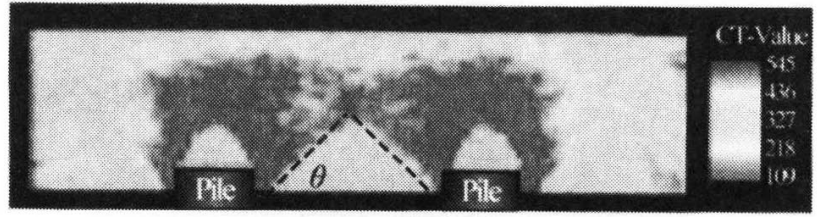

CAST2 : fathly?

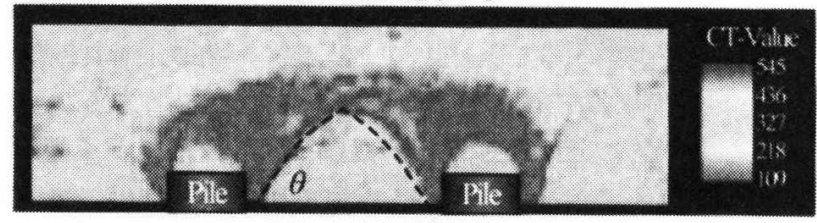

CASE3 硅砂8号

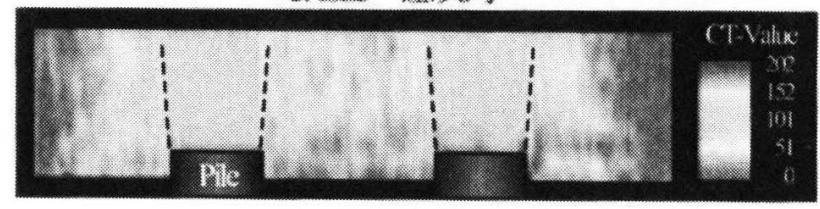

CASEA 粉体粘土

図-2 地盤特性の違いによる縦断面画像

\begin{tabular}{|c|c|c|c|}
\hline \multicolumn{4}{|c|}{ 表-4 パラメーター覧 } \\
\hline & 記号 & 盛土地盤 & 杭 \\
\hline 弾性係数 & $E\left(\mathrm{~N} / \mathrm{mm}^{2}\right)$ & 15 & 50 \\
\hline ポアソン比 & $\nu$ & 0.3 & 0.4 \\
\hline
\end{tabular}

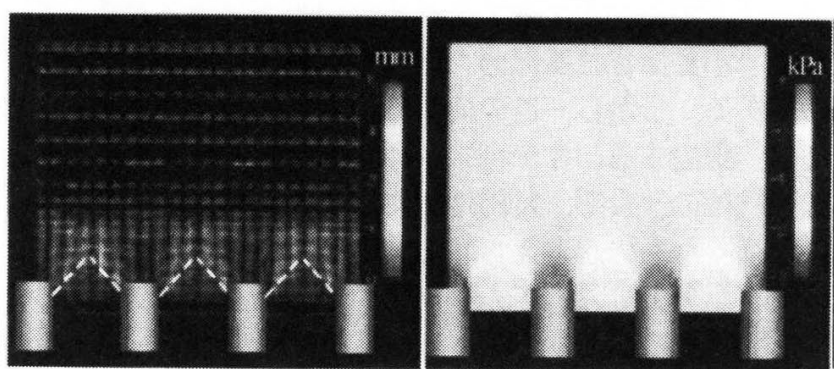

図-3 変位ベクトル図

図-4 平均有効応力図

に異なり，それぞれの杭から形成された密度変化領域は 一体化せず, 密度変化角度: $\theta$ は約 86 度である.ここで, 杭頭地盤の密度変化が杭間地盤の沈下に伴う上載荷重の 伝達に起因すると考えれば, 杭頭からの密度変化角度: $\theta$ が小さいほど広範囲に杭が荷重を分担することとなる. ここで, X 線 CT 画像における密度変化領域について考 察するために 2 次元有限要素解析を行った. プログラム は飯塚らによって開発された弾塑性有限要素プログラム （DACSAR）を一部改良したものである 。. 表-4に各パ ラメータを示す. 解析モデルは, 杭頭地盤の応力状態を 定性的に把握することを目的として 2 次元平面ひずみ条 件とし, 砂および杭体は線形弾性体とした. 拘束条件は 地盤モデルの側面を X 方向固定とし, 下面を X-Y 方向 固定とした. 解析手順は, 模型実験をシミュレートし, 


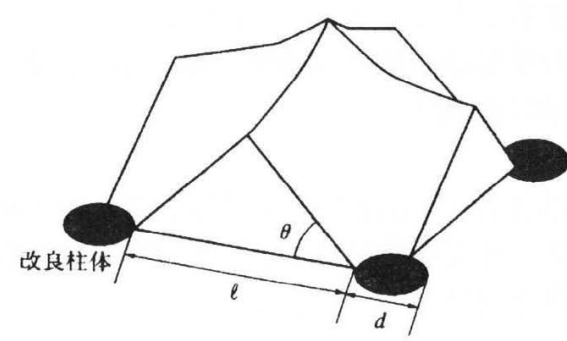

図-5未改良部に作用する盛土荷重

上載圧 $3.2 \mathrm{kPa}$ を作用させ， $5 \mathrm{~mm}$ まで段階的に沈下板を 沈下させた. なお，模型実験における側面の影響を考慮 し, 両端にも杭が連続して並んでいる状況を想定した。 図-3 に沈下板 $5 \mathrm{~mm}$ 沈下後の変位ベクトル図を色分けし て示す. 杭間地盤は沈下量と同じ $5 \mathrm{~mm}$ 程度変位し, 杭 頭地盤の変位は $3 \mathrm{~mm}$ 程度である. 変位ベクトルの境界 線は, 図-2 における密度変化領域の境界線亡非常に類 似した傾向を示していることがわかる，次に，沈下板 $5 \mathrm{~mm}$ 沈下後の平均有効応力図を図-4 に色分けして示す. 杭間地盤の $5 \mathrm{~mm}$ 程度变位した領域は, 初期地盤に対し て応力が低下している. これは, 図-2 において密度変 化がない領域に相当し，図-3において沈下量と同じ $5 \mathrm{~mm}$ 程度変位した領域であることから, 沈下板と一緒 に変位していることが伺える. 一方, 杭頭地盤は応力が 増加していることから, 沈下に伴う土のア一チ作用によ つて杭が分担している領域であることが伺える．以上よ り，X 線 CT 撮影によって得られた CT 值の増減領域は, 地盤内応力の増減領域之類似していることから, 杭頭か らの密度変化角度: $\theta$ が小さいほど広範囲に杭が何重を 分担すると考えられる. 既存の設計法 门では, 杭間の未 改良部に作用する盛土荷重を図-5 のようにモデル化し， その他の盛土荷重は杭体が受持つと考えて沈下の検討を 行う. そこで, CASE1,2 の杭間地盤において密度変化の ない領域だけを抽出した 3 次元差画像 のを図-6に示す.

この形状は, 図-5 のモデル化と非常に良く類似してお り，杭間の未改良部に作用する盛土荷重に相当する領域 であると考えられる. しかし，その領域は CASEI と CASE2 では異なることから, 荷重分担効果におけるア 一千作用は，杭頭地盤の土質特性に影響することがわか る.

\section{（2）補強材による荷重分担効果}

本節では，荷重分担効果における杭間地盤のアーチ作 用と補強材による効果について把握するため, 剛性の異 なる 2 種類のジオグリッドを用いて比較した. そのうち 豊浦砂における CASE5,6 の縦断面画像を図-7 に示す.

図-2 における CASE1 に対し, CASE5 ではジオグリッド を敷設することによって，杭頭地盤にて密度変化が卓越 するというよりは水平方向に影響範囲を広げる．杭間地 盤の密度変化角度: $\theta$ は約 28 度で発生し, 沈下に伴って 変形したジオグリッドあたりからその角度は約 60 度と 変化する. CASE6では杭間地盤の密度変化は約 25 度の

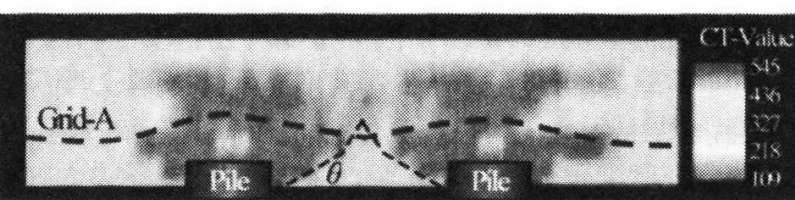

CASE5 : 豊浦砂 Grid-A敷設

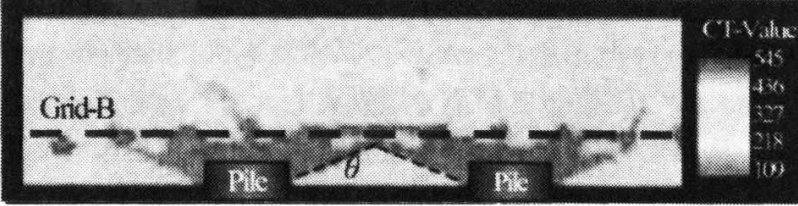

CASE6：豊浦砂 Grid-B 敷設

図-7＼cjkstart補強材の違いによる縦断面画像

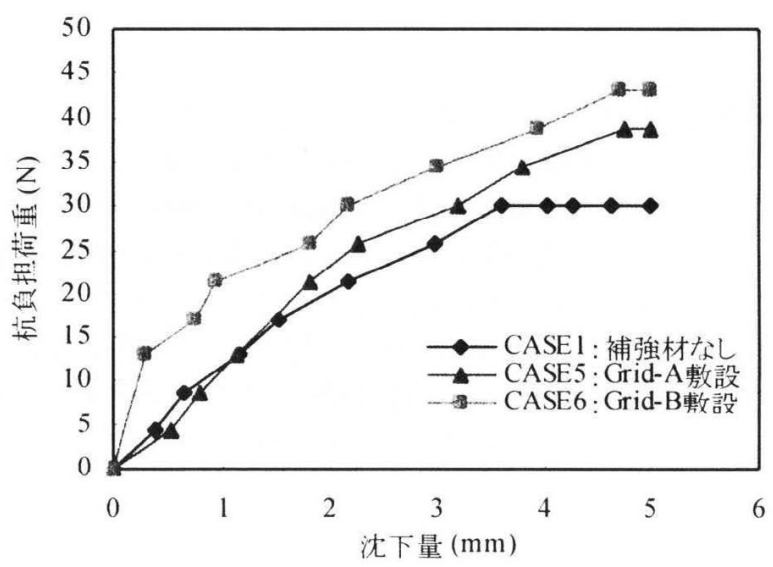

図-8＼cjkstart杭負担荷重-沈下量の関係

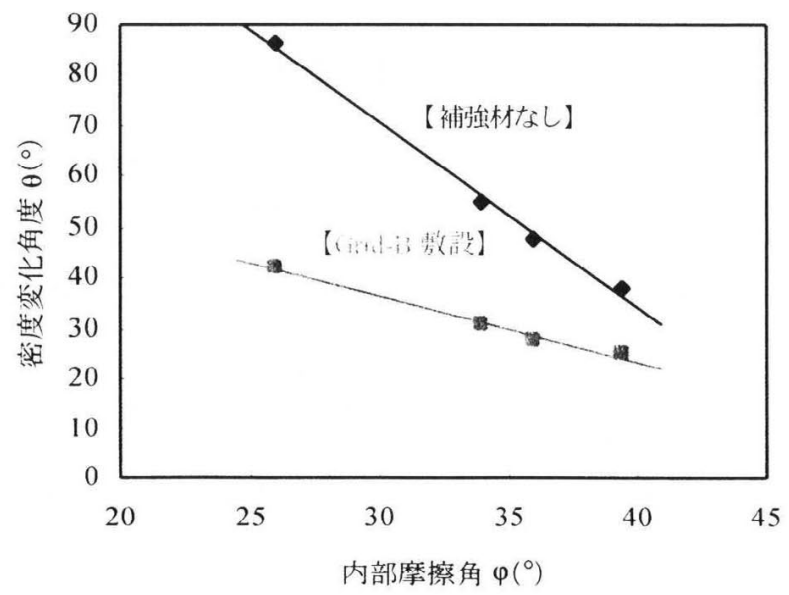

図-9 内部摩擦角 $\phi$ と密度变化角度 $\theta$ の関係 
角度で発生するが, 剛性の大きい Grid-B を敷設してい るため沈下後もジオグリッドはほとんど変形せず, 杭と ジオグリッド間にて密度変化が卓越する.これは,Grid-A に対して Grid-B の卓越した曲げ剛性が影響していると 考えられる. 次に, 図-1 に示すように模型装置の杭へ 荷重計を設置し，杭が負担する荷重を計測した．そのう ち豊浦砂における CASE1,5,6 の沈下量と杭 4 本の負担荷 重の関係を図-8 に示す. CASE1 は, 沈下に伴う杭間地 盤のア一チ作用によって杭が負担する荷重が増加し, CASE5,6 はア一チ作用に加え補強材の効果によって杭が 負担する荷重が CASE1 よりも増加する. この補強材の 効果を検討するために, 補強材なしの CASE1〜 4におけ る杭頭地盤の内部摩擦角: $\phi$ と密度変化角度: $\theta$ の関係之, Grid-B を敷設した CASE5〜9におけるその関係を図-9に 示す. 密度変化角度: $\theta$ は, いずれも杭頭地盤の内部摩 擦角: $\phi$ と負の相関関係にあることがわかる.これまで の考察より, 密度変化角度: $\theta$ が小さいほど広範囲に杭

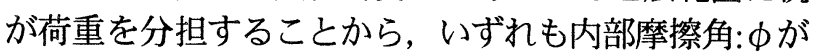
大きくなるに従って荷重分担効果も大きくなることとな る. またその効果は, 補強材を敷設することによってさ らに発揮されるが, 補強材の効果も内部摩擦角: $\phi に$ 起 因すると言える.

\section{4. おわりに}

本研究より得られた結果を下記にまとめる.

1) X 線 CT 画像における CT 值の增減領域は, FEM 解 析における地盤内応力の増減領域と類似しているこ とから, 杭頭地盤の密度変化は杭間地盤の沈下に伴 う上載荷重の伝達に起因すると考えられる.

2) $X$ 線 CT 画像における密度変化角度: $\theta$ と杭頭地盤の 内部摩擦角: $\phi$ は負の相関関係にあり, 内部摩擦角: фが大きくなるに従って荷重分担効果も大きくなる.
3）荷重分担効果は, 杭頭地盤のア一千作用に加え，補 強材を敷設することによりさらに増加する。

4) しかし，その効果は補強材の剛性および杭頭地盤の 内部摩擦角: $\phi$ に影響する.

最後に, 本研究は X線 CT 法を用いて考察したものであ る. 今後は実スケールでの検討により, 本研究で得られ た知見との相関性を確認していく所存である.

\section{参考文献}

1) (財)土木研究センター : ジオテキスタイルを用いた補強土の設 計・施工マニュアル, pp248〜256, 2000.

2) Kempfert H.G : German recommendations for reinforced embankments on pile-similar elements, EuroGeo3, pp279 284, 2004.

3) 大谷順，尾原祐三，菅原勝彦，椋木俊文 : 地盤工学における 産業用X線CTスキャナーの適用，土と基礎，Vol.48，No.2， pp.17〜20, 2000.

4) 弘中淳市, 具相仁, 大谷順, 平井貴雄 : X線CT法を用いた杭 体とジオグリッドによる荷重分担現象の可視化, 第20回ジオ シンセティックスシンポジウム論文集，pp205～210， 2005.

5) 椋木俊文 : 地盤工学におけるX線CT法の適用に関する研究, 熊本大学大学院博士学位論文, 2000 .

6) Y. Watanabe, J. Hironaka, J. Otani, T. Mukunoki : Evaluation of load transfer mechanism on deep mixing method combined with earth reinforcement technology, The $4^{\text {th }}$ Asian Joint Symposium on Geotechnical and Geoenvironmental Enginecring (投稿中), 2006.

7) 大谷順, 弘中淳市, 椋木俊文, 平井貴雄 : 鉿直荷重下におけ る杭先端地盤の3次元支持力特性, 土木学会論文集, Vol.62, No.2, pp311 319, 2006.

\title{
Load transfer effect between soil and geogrid on pile element
}

\author{
Junichi Hironaka, Youichi Watanabe, Jun Otani and Takao Hirai
}

\footnotetext{
Construction of embankments on soft ground often causes the differential settlement. Then, deep mixing method of soil stabilization and reinforcement techniques are used to reduce this settlement. This combined method offers the low improvement rate of soil stabilization by using geotextile, because embankment load is transferred to geotextile and pile element. This load transfer results from an arching effect in the reinforced embankment over the pile element heads and a membrane effect of geotextile. And it is considered that a search for the load transfer mechanism in nondestructive and 3 dimensions is important for the performance-based design. However, an interaction between soil and geotextile over the pile element heads is going issue and the real behavior has not been observed precisely. Besides this behavior itself appears in the ground so that it is difficult to check such behavior. In this paper, a series of model test for several soils and geogrids was conducted using a settlement test apparatus. The effectiveness of geogrid for the load transfer mechanisms is confirmed based on all the results using X-ray CT method.
} 